\title{
Pelatihan Pembuatan Media Pembelajaran Berbasis IT Menggunakan Software Camtasia untuk Guru Alumni Prodi PGMI Fakultas Tarbiyah
}

\author{
${ }^{1}$ Aflahah, ${ }^{2}$ Mohammad Hefni, ${ }^{3}$ Ahmad Fawaid \\ Institut Agama Islam Negeri Madura, Jl. Raya Panglegur Km. 4 Pamekasan 69371 \\ 1Aflahah84@gmail.com, ${ }^{2}$ heaven.lecture@gmail.com, \\ ${ }^{3}$ maz.ahmadfawaid99@gmail.com
}

\begin{abstract}
In the world of education, teachers are required to design IT-based learning media that are innovative, creative, efficient, and effective to increase the understanding and activeness of students in the learning process. This study describes the importance of training to make IT-based learning media by using Camtasia for the teachers who graduated from the Madrasah Ibtidaiyah Teacher Education program of Tarbiyah Faculty, Institut Agama Islam Negeri Madura. The discussion presented in this paper arises from a descriptive qualitative study since it describes the result of training to make IT-based learning media by using Camtasia software. By training the 30 teachers as participants, the result of the discussion highlights the potential of using Camtasia software media in the teaching and learning process. It can arouse the desire, interest, and motivation of students. In addition to producing student motivation and interest, IT-based learning media can also help students improve their understanding of the teacher's material.
\end{abstract}

Keywords: IT-based learning media; Camtasia Software

\begin{abstract}
Abstrak
Dalam dunia pendidikan, guru dituntut mampu merancang media pembelajaran berbasis IT yang inovatif, kreatif, efisien dan efektif sehingga dapat meningkatkan pemahaman dan keaktifan peserta didik dalam proses belajar. Penelitian ini menjelaskan pentingnya pelatihan pembuatan media pembelajaran berbasis IT menggunakan Software Camtasia untuk guru alumni program studi Pendidikan Madrasah Ibtidaiyah Indonesia (PGMI), Fakultas Tarbiyah, Institut Agama Islam Negeri Madura. Diskusi penelitian ini bermula dari penelitian deskriptif kualitatif dimana penelitian ini mendeskripsikan hasil pelatihan pembuatan media pembelajaran berbasis IT menggunakan Software Camtasia. Dengan diselenggarakannya pelatihan pada 30 guru sebagai partisipan, hasil diskusi menunjukkan potensi penggunaan Software Camtasia dalam proses belajar mengajar. Dengan pemakaian media Software Camtasia dapat membangkitkan keinginan, minat serta motivasi siswa. Selain membangkitkan motivasi dan minat siswa media pembelajaran berbasis IT juga dapat membantu siswa meningkatkan pemahaman terhadap materi yang disampaikan oleh guru.

Kata Kunci: Media Pembelajaran berbasis IT; Software Camtasia
\end{abstract}




\section{Pendahuluan}

Globalisasi yang didorong oleh three engines of globalization yang berupa international technology, global capital market, dan global management membawa pengaruh terhadap karakter pelajar saat ini yang dikenal dengan generasi milenial. Kondisi ini didukung dengan hadirnya revolusi industri era baru yaitu 4.0 yang dikenalkan di Jerman sejak tahun 2011.

Menurut Klaus Shwab (2016) menyatakan bahwa dunia telah mengalami empat tahapan revolusi industri. Pertama dimulai sejak tahun 1784 dikenalkan sistem produksi dengan tenaga air dan uap. Ke dua dimulai tahun 1870 ditemukannya tenaga listrik. Ke tiga dimulai sejak tahun 1970 dikenalkannya teknologi komputer. Ke empat dimulai tahun 2011 dikenalkan dengan era digitalisasi atau disebut dengan revolusi industri 4.0.

Era digitalisasi inilah yang telah menciptakan dunia semakin terbuka dan transparan sehingga melalui teknologi informasi (IT) informasi bisa sangat cepat diterima. Keadaan inilah yang bisa menyebabkan para generasi milenial tersebut lebih banyak mendapatkan informasi atau pengetahuan dari luar sekolah atau dari lingkungan masyarakatnya.

Fenomena ini menuntut guru untuk dapat mengembangkan media pembelajaran berbasis IT. Tujuannya agar mampu menyiapkan generasi yang akan datang siap menghadapi, mendukung, dan berkontribusi dalam perkembangan teknologi. Wena mengungkapkan guru merupakan komponen penting dari satuan pendidikan, yang memiliki tugas untuk melaksanakan proses pembelajaran. Sehingga, guru haruslah terlebih dahulu memahami IT terutama teknologi dalam pembelajaran (Wena, 2016: 12).

Dalam dunia pendidikan guru mempunyai peranan yang besar dan strategis. Hal ini disebabkan gurulah yang berada pada barisan terdepan dalam pelaksanaan pendidikan. Guru menjadi faktor utama yang menentukan proses pembelajaran bermutu atau tidak, karena guru berhadapan langsung dengan peserta didik dalam proses pembelajaran di kelas. Kecerdasan, kecakapan dan karakter peserta didik dibentuk untuk mentransfer ilmu pengetahuan dan teknologi sekaligus mendidik dengan nilai-nilai positif melalui bimbingan dan ketauladanan. Dan guna tercapanya hal tersebut perlu guru yang kompeten, bertanggung jawab, terampil, dan berdedikasi tinggi.

Guru adalah kurikulum berjalan. Sebaik apa kurikulum dan sistem pendidikan yang ada tanpa didukung oleh kemampuan guru, semuanya akan sia-sia. Guru berkompeten dan bertanggung jawab, utamanya dalam mengawal perkembangan peserta didik secara optimal. Tujuan akhir seluruh proses pendampingan guru adalah tumbuhnya pribadi dewasa yang utuh dan unggul.

Guru merupakan orang yang digugu dan ditiru dalam segala hal (Helmawati, 2016: 21). Guru digugu mengandung arti bahwa sikap dan perilaku seorang guru dapat menjadi panutan bagi lingkungannya yang perlu diikuti dan ditaati, tidak hanya terbatas dihadapan siswanya di dalam kelas, 
namun juga pada lingkungan di mana yang mereka berada. Ucapan seorang guru sebagai nasehat, bimbingan dan arahan. segala sikap seorang guru sebagai cermin kepribadian masyarakat, sikap seorang guru sebagai karakter manusia yang terpuji. Ditiru mengandung implikasi bahwa sikap dan perilaku seorang guru menjadi contoh atau suri tuladan bagi orang-orang yang ada di sekitarnya, khusus siswa-siswinya di dalam kelas dan masyarakat pada umumnya. Ucapan seorang guru penuh dengan nilainilai kebenaran, perilakunya menunjukkan perilaku yang santun bagi lingkungannya, dan sikapnya mencerminkan kasih sayang bagi sesama. Guru sering dideskripsikan sebagai manusia yang mulia karena merupakan sosok yang dipercaya karena keilmuannya dan diteladani karena perilakunya (Nurdin, 2003: 7).

Guru sebagai salah satu komponen pendidikan memberikan konsekuensi pada perlunya dibekali kemampuan secara profesional dalam melaksanakan tugas. Rasa tanggung jawab atau pengabdian dalam pelaksanaan tugas demi peningkatan kualitas pendidikan sangat diperlukan karena dalam sehari-hari, guru sekolah lain dituntut sebagai pendidik sekaligus sebagai pengajar. Untuk mewujudkan hal tersebut dibutuhkan peran serta dari semua pihak, antara lain adalah lembaga pendidikan. Berbagai upaya terlah dilakukan oleh lembaga pendidikan utuk meningkatkan mutu pendidikan, di sisi lain untuk meningkatkan kualitas pendidikan diadakannya tes setiap akhir semester untuk mengetahui prestasi siswa dalam menyerap materi pelajaran yang diberikan serta untuk mengetahui sejauh mana keberhasilan guru dalam menyajikan materi pelajaran dalam kurung waktu tertentu sesuai dengan kurikulum.

Peran guru hendaknya dapat menumbuhkan semangat siswa untuk belajar bekerja sama antara siswa dalam kelas. Proses pembelajaran harus memungkinkan tumbuh berkembang dan terpupuknya saling pengertian dalam mengembangkan hubungan antar siswa secara intensif dan berkesinambungan. Terjadinya komunikasi yang intensif antara siswa dengan guru akan meningkatkan kualitas proses pembelajaran. Proses dikatakan bermutu tinggi apabila pengkoordinasian dan penyerasian input dan proses dilakukan secara harmonis, sehingga mampu menciptakan situasi pembelajaran yang nikmat (enjoyable learning), mampu mendorong sikap percaya diri, dan benar-benar mampu memberdayakan peserta didik dalam peroses pembelajaran.

Darmawan mengungkapkan bahwa, kemajuan dibidang teknologi informasi dan komunikasi dapat dimanfaatkan pada bidang pendidikan. Misalkan dengan ide-ide pembelajaran yang sulit dipahami dan dideskripsikan akan menjadi mudah melalui animasi-animasi dan tampilan yang menarik. Melalui teknologi komputer dapat dijadikan multimedia pendidikan. Artinya bukan hanya satu media saja, tapi bisa dijadikan berbagai media (Darmawan, 2011: 4).

Salah satu media pembelajaran yang sangat popular sekarang ini adalah penggunaan video pembelajaran. Dengan bantuan video pembelajaran proses pembelajaran menjadi lebih baik (Zhang, Zhou, Briggs, \& 
Nunamaker, 2006). Hal ini didukung oleh beberapa hasil penelitian sebelumnya bahwa penggunaan visual media seperti video bisa meningkatkan kepuasan siswa dalam pembelajaran (Wang, Antonenko, \& Dawson, 2020), penggunaan video juga lebih memberikan banyak keuntungan dibandingkan menggunakan media tradisional (Greenberg \& Zanetis, 2012), Mayer (2001) juga mengkonfirmasi bahwa penggunaan elemen multimedia bisa meningkatkan semangat dan motivasi siswa.

Salah satu software yang bisa membantu membuat dan mengedit media audio visual atau video adalah Camtasia Studio. Menurut Dahtul (dalam Wirasasmita \& Putra, 2018) menjelaskan bahwa Software Camtasia adalah software untuk mengedit dan membuat video dalam bentuk rekaman layar (screencasting), tutorial, demonstrasi dan presentasi. Software ini memiliki banyak sekali keunggulan, seperti mudah digunakan, bisa menghasilkan rekaman dengan kualitas High Definition, tidak ada batasan waktu video yang bisa direkam, serta menyediakan efek visual yang baik, timelinenya pun menarik yang memudahkan pengguna untuk menambah shades, warna, dan call out pada video tersebut (Gromik, 2007). Dengan segala keunggulan tersebut, maka sangat wajar jika software Camtasia ini bisa menjadi alternatif media yang bisa digunakan untuk memproduksi perangkat pembelajaran berbasis IT, khususnya untuk memproduksi video pembelajaran.

Berdasarkan fenomena diatas, maka guru perlu menyiapkan diri dalam membuat media berbasis IT dan diaplikasikannya dalam proses belajar mengajar. Sehingga materi yang disampaikan terhadap peserta didik dapat dengan mudah terserap dan bisa membangkitkan semangat, minat serta motivasi belajar.

\section{Metode}

Pelaksanaan kegiatan PKM ini dilaksanakan pada tanggal 17-18 November 2020 yang bertempat di SD Negeri Kangenan I Pamekasan. Bertindak sebagai narasumber adalah bapak Sahrul Bahri S.Pd.SD kepala sekolah SD Negeri Kangenan I Pamekasan. Adapun kelompok sasaran dalam pengabdian ini adalah Guru Alumni Prodi PGMI Fakultas Tarbiyah IAIN Madura dari berbagai lembaga Pendidikan Madrasah Ibtidaiyah maupun SD. Dengan jumlah peserta 30 orang. Seluruh peserta dibimbing untuk dapat menerapkan hasil dari diadakannya pelatihan pembuatan media berbasis IT dengan menggunakan software camtasia dalam pembelajaran di sekolah masing-masing peserta pelatihan.

Adapun metode atau langkah-langkah pelaksanaan pelatihan ini sebagai berikut.

a. Tahap persiapan

Tahapan persiapan pelaksanaan program KPM ini adalah sebagai berikut: 
1) Rapat untuk menentukan tema, target atau sasaran program, dan menentukan sekolah mitra yang akan dijadikan tempat pelaksanaan PKM.

2) Merancang dan menentukan tanggal pelaksanaan dan pemateri pada kegiatan PKM.

3) Melakukan survey lokasi pada sekolah mitra.

4) Melakukan koordinasi dan MoU terhadap sekolah mitra dalam pelaksanaan PKM dosen Fakultas Tariyah IAIN Madura.

5) Melengkapi perlengkapan yang diperlukan dalam pelaksanaan PKM seperti akomodasi tempat, tools, konsumsi dan lain sebagainya.

b. Tahap pelaksanaan

Pada tahap pelaksanaan ini diadakan pelatihan pembuatan media pembelajaran berbasis IT dengan menggunakan software Camtasia secara intensif. Adapun rincian pelaksanaan pelatihan tersebut sebagai berikut:

1) Penyampaian Materi Workshop

Pada tanggal 17 November 2020 dilakukan pemaparan materi workshop pembuatan media pembelajaran berbasis IT, yang ditekankan pada aplikasi camtasia. Penyampaian materi ini dilakukan dengan ceramah penyampaian materi, tanya jawab dan latihan dengan menggunakan alat bantu laptop, LCD projector, dan wifi/ internet.

2) Praktik Pembuatan Media Pembelajaran

Pada tanggal 18 November 2020 dilakukan praktik pembuatan media dengan aplikasi camtasia dan dilakukan penugasan kepada peserta sebagai output hasil pelaksanaan KPM ini. Pelaksaan praktik dilakukan setelah penyampaian materi workshop. Harapanya peserta dapat lebih memahami dan mempraktikkan secara langsung pembuatan media pembelajaran yang dimaksud.

3) Penugasan

Penugasan dilakukan kepada peserta workshop untuk memperdalam pemahaman dan penguasaan materi. Output tugas yang diharapkan adalah menghasikan media pembelajaran yang brbasis IT khususnya melalui software camtasia.

\section{Hasil dan Pembahasan}

\section{a. Hasil pelaksanaan kegiatan}

Kegiatan Pengabdian Kepada Masyarakat ini telah terlaksana dengan baik dan sesuai dengan tujuan yang diharapkan. Indikator keberhasilan dalam pelaksanaan pelatihan pembuatan media pembelajaran berbasis IT menggunakan software camtasia untuk guru alumni prodi PGMI fakultas Tarbiyah ini dilakukan dengan dua metode, yaitu: (1) Evaluasi selama proses pelatihan, dan (2) evaluasi pasca pelatihan. 
Evaluasi saat pelaksanaan pelatihan meliputi, antusiasme peserta, keterlibatan dan kemampuan peserta. Antusiasme peserta sangat baik, Terbukti pada sesi tanya jawab banyak diantara peserta yang mengajukan pertanyaan. Begitu juga dengan keterlibatan dan kemampuan peserta dalam mengikuti materi pelatihan mulai dari pengenalan software-software multimedia untuk merancang video pembelajaran, Instalasi Software Camtasia, Pengenalan IDE Camtasia, Record the Screen, Record Voice Naration, Record Power Point, Record Webcam, Editing Video, Producing Video, sampai Burning Video pada Compact Disk (CD) telah dipahami peserta dengan baik.

Keberhasilan kegiatan PKM ini juga dapat dibuktikan dari hasil evalusi pasca pelatihan setelah peserta menyelesaikan tugas terbimbing. Hasil evaluasi menunjukkan bahwa taraf penyelesaian peserta dalam membuat dan mengembangkan media berupa video pembelajaran sangat baik.

Kegiatan pengabdian masyarakat ini memberi kontribusi positif kepada guru peserta workshop, karena melalui kegatan ini kemampuan guru dalam pembuatan media pembelajaran semakin meningkat dan lebih variatif dalam menentukan dan memilih media yang akan digunakan dalam pembelajaran. Melalui kegiatan ini secara tidak langsung juga akan mengoptimalkan dan memotivasi proses belajar peserta didik, sehingga peserta didik mempunyai rasa senang dalam mengikuti proses pembelajaran.

\section{b. Pembahasan}

Kata media berasal dari bahasa Latin medius yang secara harfiah berarti tengah, perantara atau pengantar. Dalam bahasa Arab media adalah perantara atau pengantar pesan dari pengirim kepada penerima pesan. Media menurut pengertian $\mathrm{KBBI}$ adalah alat, sarana komunikasi, penghubung, atau yang terletak di antara dua pihak (orang, golongan, dan sebagainya) (Arsyad, 2014: 3).

Asosiasi Teknologi dan Komunikasi Keguruan (Association for Education and Communication Technology/AECT) mendefinisikan media sebagai benda yang dapat dimanipulasikan, dilihat, didengar, dibaca, atau dibicarakan beserta instrumen yang dipergunakan dengan baik dalam kegiatan belajar mengajar, dapat mempengaruhi efektifitas program instruksional (Arsyad, 2014: 3).

Sementara yang dimaksud Media berbasis informasi teknologi (IT), adalah media yang didukung oleh hal-hal yang berkaitan dengan teknologi informasi seperti: radio, TV, komputer, telepon, dan sebagainya. Dan pada umumnya media berbasis IT selalu menawarkan sesuatu yang menarik. Sehubungan dengan hal tersebut, maka peran media berbasis IT menjadi sangat penting. Media ini dapat bersifat visual, non-visual, maupun yang lainnya. Dan media berbasis IT ini dapat dikategorisasikan sebagai multimedia dalam pembelajaran (Arsyad, 2014: 162).

Media pembelajaran yang digunakan dalam kegiatan pembelajaran dapat mempengaruhi terhadap efektivitas pembelajaran. Pada mulanya media pembelajaran hanya berfungsi sebagai alat bantu guru mengajar, alat bantu 
visual dan media pembelajaran grafis. Namun sejak abad ke-20 pemanfaatan visual kemudian dilengkapi dengan audio sehingga lahirlah alat bantu audio visual. Sejalan dengan perkembangan ilmu pengetahuan dan teknologi atau IPTEK, khususnya dalam bidang pendidikan saat ini penggunaan alat bantu atau media pembelajaran menjadi semakin luas dan interaktif. Seperti adanya komputer dan internet. Dalam kegiatan belajar mengajar, sering pula pemakaian kata media pembelajaran digantikan dengan istilah seperti alat pandang dengar bahan pengajaran kemudian pandang dengar pendidikan alat peraga pandang alat peraga teknologi pendidikan alat peraga dan media penjelas.

Dan Berdasarkan dari hasil pelaksanaan pelatihan selama dua hari tersebut, pelaksanaan Pengabdian Kepada Masyarakat (PKM) dengan judul pelatihan pembuatan media pembelajaran berbasis IT menggunakan software camtasia untuk guru alumni prodi PGMI fakultas Tarbiyah ini mampu meningkatkan pengetahuan guru dalam memilih, menenukan, membuat media pembelajaran yang lebih variatif dan menyenangkan, sehingga dapat memotovasi semangat belajar peserta didik yang tentunya akan meningkat prestasi akademiknya.

Software Camtasia merupakan perangkat lunak (software) yang dikembangkan oleh TechSmith Coorporation khusus bidang multimedia. Camtasia Studio adalah program aplikasi yang dikemas untuk recording, editing, dan publishing dalam membuat video presentasi yang ada pada layar (screen) komputer. Camtasia studio adalah software untuk meng capture tampilan layer monitor, dengan ditambahi audio dan video, bisa juga kita gunakan untuk merekam hasil presentasi powerpoint ke dalam format video. Camtasia Studio dapat membantu dan melatih kita dalam menyampaikan serta berinteraksi dengan audiens. Camtasia Studio memiliki kemampuan untuk merekam suara yang ada dalam layar, termasuk kegiatan di desktop, presentasi powerpoint, narasi suara, dan webcam video (Aripin, 2011: 2).

Adapun cara penggunaannya sebagai berikut. Camtasia Studio 5 bekerja dengan tiga tahap, yaitu recording, editing dan publishing.

1) Recording Camtasia recorder adalah sebuah komponen screen recording sederhana yang powerfull untuk meng-capture pergerakan kursor, memilih menu, pop-up windows, layer windows, dan teks yang dapat dilihat pada layar. Camtasia recorder menyediakan fitur untuk menggambar pada screen, menambah teks tulisan dan efek ketika merekam (recording). Dengan fitur camtasia studio recording, anda dapat: (a) Merekam semua atau beberapa bagian pada layar (screen), seperti menekan mouse dan tombol. (b) Merekam presentasi powerpoint, seperti narasi, audio, slide transitions, animasi dan keterangan lainnya. (c) Merekam suara audio mikrofon dan aplikasi audio, seperti webinar audio, efek suara, menekan mouse, dan mengetik dengan keyboard. (d) Menggambar dan highlight pada screen dengan menggunakan 
ScreenDraw, dan (e) Merekam keterangan gambar dan ScreenDraw, menggunakan hotkeys untuk memperkecil dan memperbesar.

2) Editing Pada menu camtasia studio 5, kita dapat mengimport video, audio, dan file gambar kedalam project. File dapat di import dengan sangat mudah dan sederhana dengan cara menge-drag drop file yang terletak dalam clip bin kedalam Timeline, kemudian edit sesuai keinginan.

3) Publishing Dalam dukungan video atau animasi, camtasia studio 5dapat menjakau berbagai audiens. Kita dapat menyampaikan video kita dengan berbagai cara, diantaranya CD-ROOM, Flash, Web, DVD dan e-mail (Aripin, 2011: 2).

Keberhasilan tersebut sesuai dari fungsi penggunaan media pembelajaran dalam proses belajar mengajar yang dapat membangkitkan keinginan, minat, motivasi dan rangsangan kegiatan belajar bahkan membawa pengaruh psikologi siswa. Penggunaan media pembelajaran pada tahap orientasi pembelajaran akan sangat membantu keefektifan proses pembelajaran dan penyampaian pesan dan sisi pelajaran (Hamalik, 1994: 26). Selain membangkitkan motivasi dan minat siswa, media pembelajaran juga dapat membantu siswa meningkatkan pemahaman menyajikan materi yang menarik dan memudahkan penafsiran materi.

Dan Secara umum manfaat media pembelajaran adalah memperlancar interaksi antara guru dan siswa sehingga kegiatan pembelajaran akan lebih efektif dan efisien. Tetapi secara khusus ada beberapa manfaat media yang lebih rinci. Sudjana dan Rivai mengidentifikasikan beberapa manfaat media pembelajaran yaitu:

1) Pengajaran akan lebih menarik perhatian siswa sehingga dapat menumbuhkan motivasi belajar.

2) Bahan pengajaran akan lebih jelas maknanya sehingga dapat lebih dipahami oleh para siswa, dan memungkinkan siswa menguasai tujuan pengajaran lebih baik.

3) Metode mengajar akan lebih bervariasi, tidak semata-mata komunikasi verbal melalui penuturan kata-kata oleh guru, sehingga siswa tidak bosan dan guru tidak kehabisan tenaga, apalagi bila guru mengajar untuk setiap jam pelajaran.

4) Siswa lebih banyak melakukan kegiatan belajar, sebab tidak hanya mendengarkan uraian guru, tetapi juga aktivitas lain seperti mengamati, melakukan, mendemonstrasikan dan lain-lain (Sudjana \& Rivai, 2010: 2). Sementra Levie dan Lentz (1982) mengemukakan empat fungsi media pembelajaran sebagai berikut:

1) Fungsi atensi, media visual merupakan inti, yaitu menarik dan mengarahkan perhatian siswa untuk berkonsentrasi kepada isi pelajaran yang berkaitan dengan makna visual yang ditampilkan atau menyertai teks materi pelajaran. Seringkali pada awal pelajaran siswa tidak tertarik dengan materi pelajaran atau mata pelajaran, yang merupakan salah satu pelajaran yang tidak disenangi oleh mereka, sehingga mereka tidak 
memperhatikan. Dengan penggunaan media, khususnya gambar yang diproyeksikan melalui projector dapat menenangkan dan mengarahkan perhatian mereka kepada pelajaran yang akan mereka terima. Dengan demikian kemungkinan untuk memperoleh dan mengingat isi pelajaran semakin besar.

2) Fungsi afektif, media visual dapat terlihat dari tingkat kenikmatan siswa ketika belajar atau membaca teks yang bergambar-gambar atau lambang visual dapat menggugah emosi dan sikap siswa misalnya informasi yang menyangkut masalah sosial atau ras

3) Fungsi kognitif, media visual terlihat dari temuan-temuan penelitian yang mengungkapkan bahwa lambang visual atau gambar memperlancar pencapaian tujuan untuk memahami dan mengingat informasi atau pesan yang terkandung dalam gambar tersebut

4) Fungsi kompensatoris, media pembelajaran terlihat dari hasil penelitian bahwa media visual yang memberikan konteks untuk memahami teks membantu siswa yang lemah dalam membaca untuk mengorganisasikan informasi dalam teks dan mengingatnya kembali. Dengan kata lain media pembelajaran berfungsi untuk mengakomodasi kan siswa yang lemah dan lambat menerima dan memahami isi pelajaran yang disajikan dengan teks atau disajikan secara verbal.

Kenyataan menunjukkan bahwa efektivitas pembelajaran atau proses belajar mengajar sering tidak tercapai secara optimal. Hal ini disebabkan karena pembelajaran sebagai suatu proses komunikasi sering dihadapkan kepada berbagai kendala. Diantaranya yaitu adanya kecenderungan verbal, ketidakpastian, kurangnya minat, gairah dan lain-lain. Pemanfaatan media dalam proses pembelajaran adalah merupakan salah satu upaya untuk mengatasi keadaan tersebut, mengingat fungsi media dalam proses pembelajaran selain sebagai penyanyi stimulus juga untuk meningkatkan keserasian terutama dalam menerima informasi. Disamping itu, media juga berfungsi sebagai perantara antara guru dengan siswa. Dan dalam hal tertentu media berfungsi untuk mengatur langkah-langkah kemajuan serta untuk memberikan umpan balik.

Moldastad (dalam Bachtiar, 1984) menyatakan bahwa teknologi instruksional dalam proses pembelajaran akan dapat menimbulkan kondisikondisi positif seperti:

1) Belajar lebih banyak terjadi jika media diintegrasikan dengan program internasional yang tradisional

2) Jumlah belajar yang setara sering dapat tercapai dalam waktu yang lebih singkat dengan menggunakan teknologi instruksional

3) Program instruksional dengan menggunakan media yang bermacam didasarkan pada suatu pendekatan sistem seringkali memudahkan siswa dalam belajar secara lebih efektif

4) Program program multimedia dan atau tutorial audio untuk pembelajaran biasanya lebih disukai siswa bila dibandingkan dengan pengajaran tradisional. 
Dan dalam penggunaan media harus memperhatikan prinsip pemilihan media terlebih dahulu. Prinsip-prinsip dalam pemilihan media pembelajaran menurut Saud adalah sebagai berikut:

1) Tepat guna, artinya media pembelajaran yang digunakan sesuai dengan kompetensi dasar.

2) Berdaya guna, artinya media pembelajaran yang digunakan mampu meningkatkan motivasi siswa.

3) Bervariasi, artinya media pembelajaran yang digunakan mampu mendorong sikap aktif siswa dalam belajar (Syaefuddin, 2010: 97).

Keberhasilan penggunaan media pembelajran berbasis IT, seperti dalam pelatihan yang dilakukan selama dua hari berturut-turut. Merupakan suatu kompetensi yang harus dimilki dan dikuasai guru sesuai tuntutan UU pasal 8 No. 14 th 2005 tentang pendidikan nasional. Ada beberapa kompetensi yang harus di miliki oleh seorang guru dalam mendidik, yaitu bahwa seorang pendidik/guru harus memiliki kompetensi sosial, kepribadian, profesional dan pedagogik. Dari ke empat kompetensi tersebut dapat di diskripsikan sebagai berikut:

1) Kompetensi sosial, Dalam kompetensi ini seorang guru diharapkan dapat menjadi pemicu semangat peserta didik dengan memberikan pengajaran tentang berbahasa dan tetap memegang norma - norma dalam bergaul baik di ligkungan sekolah maupun di luar lingkungan sekolah.

2) Kompetensi Kepribadian, seorang guru harus memiliki kepribadian yang berwibawa dan mampu membawa diri, karena guru merupakan sorotan dan panutan dari peserta didiknya.

3) Kompetensi Profesional, dalam kompetensi ini seorang guru harus mampu menguasai situasi ketika mengajar dan tidak, selain itu guru juga harus menguasai materi dan juga memiliki intepretasi yang tinggi sehingga kegiatan belajar mangejar dapat berlangsung dengan baik.

4) Kompetensi Pedagogik, dalam hal ini guru harus memberikan pemahaman kepada peserta didiknya dengan cara mengaktualisasikan wawasan yang ia miliki kedalam pengajaran yang dialogis. Mampu memanfaatkan teknologi, mengembangkan kurikulum dan juga mengevaluasi pembelajaran (Mulyasa, 2007: 40).

Dari empat kompetensi tersebut yang terkait dengan pentingnya guru menguasai media pembelajaran berbasis IT yaitu pada kompetensi pedagogik yang berkaitan dengan kemampuan guru dalam mengelola dan pemanfaatan teknologi informasi dalam pembelajaran. Maka dari itu, seorang guru harus memiliki kualifikasi dan kompetensi tersebut guna meningkatkan kualitas pembelajaran dan tercapainya cita-cita pendidikan nasional. Guru diharapkan secara berkesinambungan dapat meningkatkan kompetensinya secara profisional. Guru harus memiliki keahlian khusus dalam menjalankan tugas-tugas profesionalnya. Mengingat strategis peran yang dimiliki oleh seorang guru sangat urgen dalam membentuk peserta 
didik yang unggul, maka usaha-usaha untuk mengenali dan mengembangkan profesionalitas guru menjadi sangat penting untuk dilakukan.

\section{Kesimpulan}

Berdasarkan pelaksanaan pengabdian kepada masyarakat dengan pemanfaatan media pembelajaran berbasis IT dengan menggunakan software camtasia dapat meningkatkan pengetahuan dan keterampilan guru alumni prodi PGMI fakultas Tarbiyah dalam mengembangkan media pembelajaran berbasis IT. Dan dengan pelatihan ini pula para guru alumni prodi PGMI fakultas Tarbiyah dapat menerapkannya dalam proses pembelajaran. Sehingga memberikan pengaruh yang besar dalam menarik perhatian siswa dalam proses pembelajaran, karena pada dasarnya media mempunyai dua fungsi utama, yaitu media sebagai alat bantu dan media sebagai sumber belajar bagi siswa.

\section{Daftar Pustaka}

Aripin. (2011). Step by Step Membuat Video Tutorial Menggunakan Camtasia Studio. Bandung: Remaja Rosdakarya.

Arsyad, A. (2014). Media Pembelajaran. Jakarta: PT. Raja Grafindo Persada.

Bachtiar, H. W. (1984). Media dalam Pembelajaran. Jakarta: CV. Rajawali.

Darmawan, D. (2011). Teknologi Pembelajaran. Bandung: Remaja Rosdakarya.

Greenberg, A. D., \& Zanetis, J. (2012). The Impact of Broadcast and Streaming Video in Education: What the Research Says and How Educators and Decision Makers Can Begin to Prepare for the Future. Cisco Systems Inc. to Wainhose Research, LLC. Retrieved from Cisco Systems Inc. to Wainhose Research, LLC website: https://www.cisco.com/c/dam/en_us/solutions/industries/docs/educatio n/ciscovideowp.pdf

Gromik, N. (2007). Video Tutorials: Camtasia in the ESL Classroom. JALT CALL Journal, 3(1), 132-140.

Hamalik, O. (1994). Media Pendidikan. Bandung: PT. Citra Adya Bakti.

Helmawati. (2016). Pendidik sebagai Model. Bandung: PT. Remaja Rosdakarya.

Levie, W. H., \& Lentz, R. (1982). Effects of Text Illustrations: A Review of Research. ECTJ, 30(4), 195-232. doi: 10.1007/BF02765184

Mayer, R. E. (2001). Multimedia Learning. New York: Cambridge University Press.

Mulyasa, E. (2007). Standar Kompetensi dan Sertifikasi Guru. Bandung: Remaja Rosdakarya.

Nurdin, S. (2003). Guru Profesional dan Implementasi Kurikulum. Jakarta: Ciputat Pers. 
Schwab, K. (2016). The Fourth Industrial Revolution. New York: Crawn Business.

Sudjana, N., \& Rivai, A. (2010). Media Pengajaran. Bandung: SInar Baru Algensindo.

Syaefuddin, S. U. (2010). Pengembangan Profesi Guru. Bandung: Sinar Baru Algesindo.

Wang, J., Antonenko, P., \& Dawson, K. (2020). Does Visual Attention to the Instructor in Online Video Affect Learning and Learner Perceptions? An Eye-Tracking Analysis. Computers \& Education, 146, 103779. doi: 10.1016/j.compedu.2019.103779

Wena, M. (2016). Strategi Pembelajaran Inovatif Kontemporer Suatu Tinjauan Konseptual Operasional. Jakarta: Bumi Aksara.

Wirasasmita, R. H., \& Putra, Y. K. (2018). Pengembangan Media Pembelajaran Video Tutorial Interaktif menggunakan Aplikasi Camtasia Studio dan Macromedia Flash. Edumatic: Jurnal Pendidikan Informatika, 1(2), 35-43.

Zhang, D., Zhou, L., Briggs, R., \& Nunamaker, J. (2006). Instructional Video in e-Learning: Assessing the Impact of Interactive Video on Learning Effectiveness. Information \& Management, 43(1), 15-27. doi: 10.1016/j.im.2005.01.004 